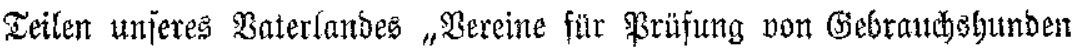

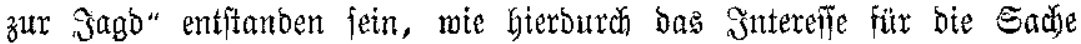
allentbalben gewedt, Erfahrungen alsgetaujat, neue Gejichtspunte er= offinet worden jeien, wie aber insbejondere bie von ihm felbft in worftehen=

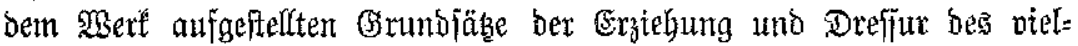

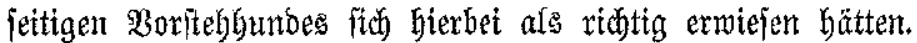

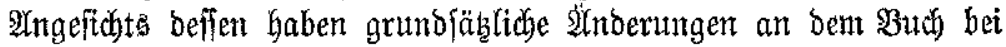
ber jeşigen Neutuffage nidyt ftattgefunden, wohl aber mancherlet Ers=

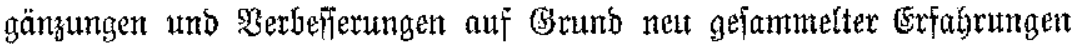

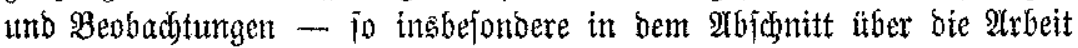

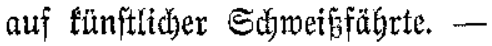

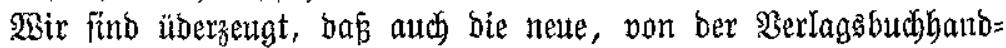

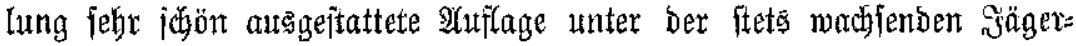

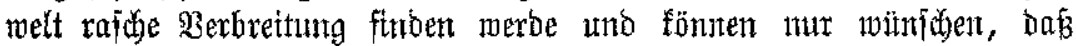
audi) bie Mabnungen bes Berfaffers zu weidgeredyter 2 Husitbung ber sags, bie ung in bem $\mathfrak{B u d}$ allenthalben entgegen treten, auf gutent Bobent fallen ntögen.

F.

\title{
IV. Mlotiz̨ren.
}

\section{Dentmal für Elias Landolt.}

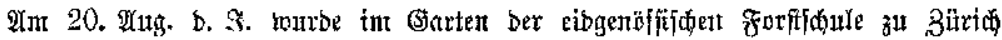
bas auf Anregung bes Sdweizer Forftwereins exridete Denfmal für ben im Sabre $1896^{2}$

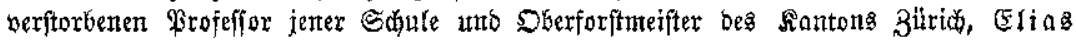

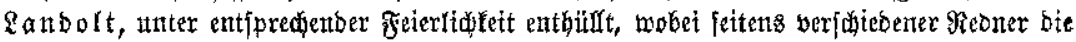

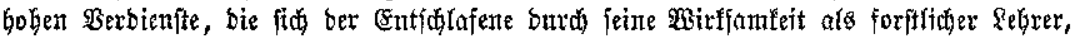

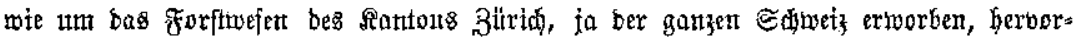

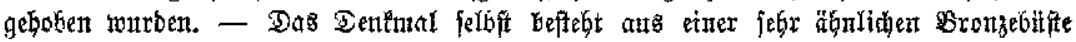

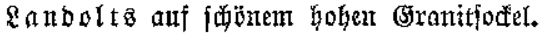

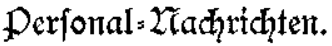

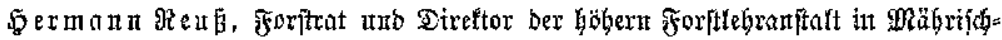

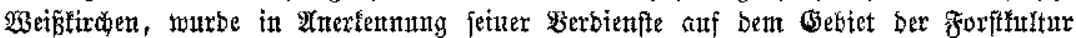

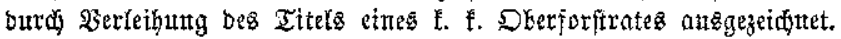

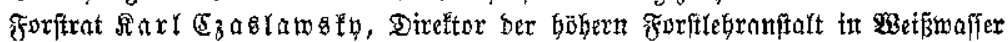

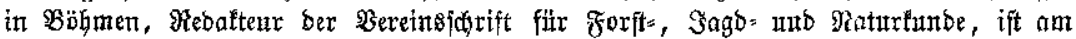
6. Sutt 1899 geitorken.

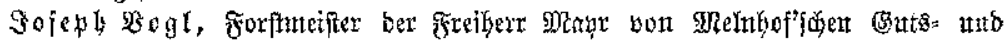

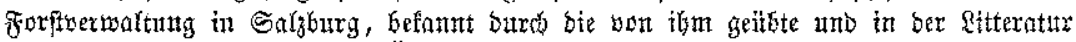

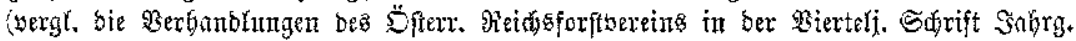

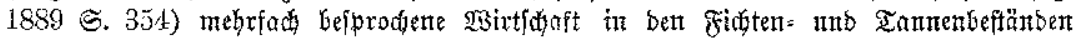

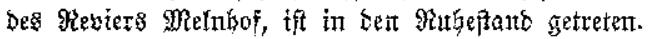

